\title{
DTX2 wt Allele
}

National Cancer Institute

\section{Source}

National Cancer Institute. DTX2 wt Allele. NCI Thesaurus. Code C106466.

Human DTX2 wild-type allele is located in the vicinity of 7q11.23 and is approximately 44 kb in length. This allele, which encodes probable E3 ubiquitin-protein ligase DTX2 protein, is involved in regulation of Notch signaling. 